The effect of contamination from churns on the bacteriological and keeping quality of both raw and pasteurized milk was the subject of another paper. There is in general no measurable effect, unless the number of bacteria added by the churns is at least equal to that initially present in the milk. Churns which have been mechanically washed efficiently are without effect on the keeping quality of the milk, and no advantage accrues from further steam sterilization of such churns.

The Proceedings of the Society, containing full abstracts of the papers read at the conference, may be purchased from the honorary treasurer.

\section{BRITISH ELECTRICAL ENGINEERS AND THE WAR}

$\mathbf{A}^{\mathrm{T}}$ $T$ the opening meeting on October 4 of the current session of the Institution of Electrical Engineers, Dr. P. Dunsheath delivered his presidential address, in the course of which he gave a broad survey of some of the contributions made by British electrical engineers to the successful outcome of the greatest war in history. The scope of the address was very wide and covered such subjects as the maintenance of the electric power supply of Great Britain, the considerable increase in communications both at home and overseas, the use of broadcasting and radar as defensive and offensive weapons, the defeat of the magnetic mine, radio aids to navigation and gun-laying, the improvement of searchlights and the development of electrical equipment for research on atomic energy. The success attained in all this work was in no small measure due to the extensive and ready co-operation which was built up between the Services and the electrical industry for the purpose of solving the many problems of design and production which continually arose. In giving some general facts about the above contributions, Dr. Dunsheath disclosed some striking figures concerning the various phases of electrical engineering as adapted to war-time requirements.

The problem of the maintenance of an adequate electric power supply had to be tackled in the face of such difficulties as the destruction of, or severe damage to, certain generating stations by enemy bombing, and the interruption of service due to the breakdown of the overhead wires of the Grid system. The large majority (about 73 per cent) of the faults on this overhead distribution system were caused by trailing cables of barrage balloons which had broken loose; and only some 14 per cent were directly attributable to enemy action. For strategic reasons it became necessary early in the War to effect a major transfer of munition works to South Wales and the south-west of England; and the resulting change in load distribution imposed a very onerous task on the national control organization of the Central Electricity Board. Having in mind the additional difficulties of obtaining materials, suitable coal and adequate labour, there can be no question that the successful operation of a system of public supply stations with an output in 1944 of more than 38,000 million $\mathrm{kWh}$., which was an increase of nearly one half on the 1939 output, is an outstanding performance.

As the supply of electric power for industrial purposes was a prime war-time necessity, so was the maintenance and extension of communications be- tween different parts of the country and overseas. In this field the British Post Office provided a vast private-circuit network for the operational, meteorological and administrative traffic of the Fighting and allied Services, and enlarged its peace-time trunk system to reduce delays in priority traffic concerned mainly with the supply of munitions. Much progress was made during the War in the equipment used on audio carrier current and coaxial cable systems with the object of making each circuit carry as many communication channels as possible. Where it was necessary or expedient, radio links operating on ultrashort wave-lengths were installed and used as an integral part of the land-line network. In spite of various precautions taken before and during the War, many disasters due to enemy action overtook the Post Office. For example, a single high-explosive bomb on the Old Bailey on May 10, 1941, severed 28 cables of different types and interrupted 5,200 working circuits, mainly long-distance.

Overseas communications for the Services, necessarily of a secret nature, were carried out mainly by the submarine cable system, a network of 155,000 nautical miles which suffered many vicissitudes during the War due to enemy action and other causes. The enormous quantities of Press traffic, etc., were mainly cleared on wireless circuits; and on the longdistance service an outstanding war-time technical development was the extension of relay working to avoid interruption of the service by unsuitable ionospheric conditions. Another remarkable development in British electrical engineering enterprise during the War was in connexion with the wireless transmission of photographs, drawings, etc. Although the whole of the London photo-telegraph apparatus was lost during the raids of May 1941, the number of circuits on which photographs can be transmitted. has been increased from three to eleven, and some two thousand facsimiles are now being exchanged monthly over direct circuits between London and the principal cities of the world.

The British broadcasting service was outstanding during the whole of the War in providing entertainment, news and stimulating programme items so necessary in keeping public morale at a high level. In addition, an important job, not perhaps adequately appreciated by British listeners, was carried out in providing listeners in the occupied countries of Europe with their only access to truth in news and their only means of contact with the world outside Nazi domination. As a result of the war-time efforts of our electrical engineers, Great Britain now possesses the world's largest long-wave broadcasting station, capable of delivering to the aerials a power of $800 \mathrm{~kW}$., as well as the world's largest short-wave broadcasting station, at which there are twelve transmitters, each capable of delivering $100 \mathrm{~kW}$. to one or other of the fifty-one directional beam aerials. In order to improve home reception and to provide for local broadcasting in the event of the interruption of communications due to invasion, the B.B.C. built sixty-four small broadcasting stations, which were synchronized and operated on one wave-length-an outstanding technical achievement. These were finally closed on July 28, 1945, when the Corporation changed over to the first instalment of peace-time broadcasting.

During his address, Dr. Dunsheath referred at some length to the development and applications of radar, both as a defensive and as an offensive instrument of war. This technique, developed first as a means of detecting attacking enemy aircraft, and later used 
as an entirely novel form of navigation and for the precision bombing of enemy targets on and, sea or in the air, is now well known as one of the outstanding achievements of the War, in which scientific workers, engineers, industry and the Services have co-operated with complete success. This work brought in its train remarkable developments in the technique and output of valves, cables with novel dielectrics, cathode ray tubes and many other components. The facts that a modern battleship carries about fifty transmitting sets of various kinds, and many more receiving sets, and that a Lancaster bomber fully equipped may require about four hundred valves, accounts for the statement that during the last year of the War thirty-eight million thermionic valves were produced for the Services as compared with a peace-time demand of a quarter of a million.

There are many other electrical engineering applications which have been exploited to the full during the War, such as the clearing of fields of magnetic mines and the fitting of ten thoasand warships and merchant vessels with degaussing equipment, the improvement of searchlights and their automatic direction by radar control, and the lighting of ports, shipyards and other important open areas under conditions of severe restrictions.

Dr. Dunsheath was only able to make a passing reference to the importance of the corporate work of the Institution of Electrical Engineers, and to the teaching profession, in providing an adequate supply of trained and experienced personnel of all grades. Without the assistance of large numbers of trained. personnel, many of the engineering and scientific achievements of the electrical engineer during the War would never have come to fruition.

\section{SCIENTIFIC STUDY OF FELLMONGERING}

$\mathrm{T}$ HE wool trade and, later, the cloth trade are the two industries on which the wealth of medieval England was founded, and wool production is still one of the leading industries of the British Empire. Though large quantities of wool are taken from the living sheөp at the annual shearing, a good deal comes from slaughtered sheop. The handling of the sheepskin after flaying, and the separation of the wool from the pelt, are the tasks of the fellmonger, who in many cases is carrying out his work to-day by the same methods as those employed by his ancestors hundreds of years ago. Fellmongering, however, like a number of other ancient crafts, has now become the subject of scientific research. Bulletin No. 184, recently issued by the Council for Scientific and Industrial Research of Australia (Melbourne: Gov. Printer, 1945), describes a series of important fundamental investigations on the fellmongering process carried out by F. G. Lennox, Margaret Maxwell and W. J. Ellis.

There are, speaking very roughly, two types of sheөp farmed in Australia : the Merino sheөp, with long fine wool and, even at best, a poor pelt, and the crossbred sheep with shorter, coarser wool and a better pelt. There are also two general methods of de-wooling. The older process, with origins lost in antiquity, is known as 'sweating'-the sheepskins are hung in a warm moist atmosphere until the wool loosens and can be pushed off the pelt by the hand, the wool fibre coming away complete with root. The more recent process is 'painting'; the skins are covered on the flesh side with a thick cream of lime and a reducing agent, generally sodium sulphide, and the alkali plus reducing agent travel through the skin and cause the wool fibre to break off just above the root. The painting process therefore leads to a slight shortening of the fibre, and the total loss of weight from this cause is sufficient to keep the older sweating process in being for Merino sheepskins, in spite of the considerable damage frequently done to the pelt, and the foul odour of the sweating chambers.

The present pamphlet contains twelve papers describing studies on wool-loosening by the sweating process, the effect on the pelt not being included. It is interesting that the foundation of the work is the development of a quantitative method for measuring the force required to detach a standard staple from the pelt. With this tool in the hands of the investigator, it becomes possible to study, with some accuracy, the effect of varying conditions on the rate at which the wool root is loosened from its base.

The active agents in the sweating process are bacteria; an ærobe, an atypical strain of Proteus vulgaris designated No. 7, being the dominant woolloosening organism, though three or four other species also have the same effect. No. 7 exists sparsely at the wool roots at the start of the sweating process, and freely when the wool is ready to pull. The agents of putrefaction which damage the pelt are anærobes. Many skins from up-country kills are dried for transport and have to be soaked back by the fellmonger before they ean be sweated. Studies of this soaking operation show that the soak-water is completely de-oxygenated, a condition which oncourages the growth of putrefactive anærobes. This, however, does not appear to inhibit the growth of No. 7 in the sweating chambers, and oxygenating the soak-water does not accelerate wool-loosening.

During sweating a large amount of ammonia is produced. Ammonia itself has a wool-loosening action, but the accumulation of ammonia tends to inhibit bacterial wool-loosening. The action of ammonia is due to the $\mathrm{NH}_{3}$ molecule. Aliphatic amines have a similar effect, though this diminishes with increasing size of the molecule, quaternary ammonium compounds having little activity. Lipid solvents similarly have a wool-loosening action, while reagents causing dehydration, such as acetone and solutions of sodium chloride, and even drying, have a wool-tightening action. Conditions which cause tissue-swelling also cause tightening, probably because the hair-bulb cannot pass up the follicle.

The impression left on the reader of the twelve papers is of work well planned, well executed and well reported. An interesting development of the research is a new method of de-woolling the numerous small scraps from the edges of skins treated by the painting process, as well as shanks and head pieces. In these the scraps of pelt have no commercial value, and it has been shown that by subjecting them to heat treatment at $65^{\circ} \mathrm{C}$. the skin tissues can be completely hydrolysed by proteases prepared from a bran culture of Aspergillus flavus-oryzae or by papain, leaving the wool undamaged.

The volume well illustrates how even the oldest craft can be improved by an understanding of its scientific basis, and further developments will be awaited with great interest.

D. JORDAN LLOYD. 